\title{
PENDIDIKAN KARAKTER BERBASIS AL-QUR'AN: Penerapan Pola Sistematika Nuzulnya Wahyu (SNW) di Pondok Pesantren Hidayatullah Panyula Kabupaten Bone
}

\author{
Afifuddin \\ UIN Alauddin Makassar DPK Fakultas Agama Islam Univ. Islam Makassar \\ Jl. Urip Sumoharjo Nomor 36 Makassar \\ afifuddinhrs@gmail.com
}

\begin{abstract}
Abstrak:
Artikel penelitian ini mengkaji dan membahas tentang Pola Sistematika Nuzulnya Wahyu (SNW) yang diterapkan di Pondok Pesantren Hidayatullah Panyula Kabupaten Bone. Penelitian ini berfokus pada penerapan pola SNW tersebut dalam rangka pembentukan karakter qur'ani di pesantren tersebut. Dengan metode kualitatif deskriptif, peneliti mengumpulkan dan menganalisis data-data lapangan dan menemukan bahwa Pondok Pesantren Hidayatullah telah berhasil menerapkan metode-metode pendidikan berbasis Alquran untuk membentuk karakter mulia para santrinya. Dengan berpedoman pada sistematika turunnya wahyu, pesantren ini melakukan proses kaderisasi dan internalisasi nilai sebagaimana yang dilakukan oleh Nabi Muhammad saw. di awal dakwahnya di Mekah. Penelitian ini bertujuan memberikan kontribusi akademik kepada para pendidik dalam rangka membentuk karakter islami peserta didiknya.
\end{abstract}

\begin{abstract}
:
This article discusses about the pattern of descent of revelation systematics applied in hidayatullah boarding school, Panyula, Bone regency. This research focuses on the implementation of the pattern of descent of revelation systematics in accordance with the qur'anic character building at the boarding school. The researcher collected and analized data by using descriptive qualitative. This research found that hidayatullah boarding school has successfully applied educational methods on quranic based to build students' character. Based on the descent of revelation systematics, it has regenerated and internalized values as what have been done by the Prophet Muhammad in his first dakwah in Mecca. This research aims to give academic contribution to teachers in order to build Islamic character of the students.
\end{abstract}

Kata kunci:

Pendidikan, Epistemologi, Dikotomi, Pembaruan

PENDIDIKAN secara umum bertujuan mencetak dan membangun manusia Indonesia seutuhnya. Dalam hal ini dipahami bahwa pendidikan, khususnya pendidikan agama, tidak hanya menyiapkan manusia yang unggul dari segi intelektualitasnya saja, tetapi lebih dari itu pendidikan berupaya seoptimal mungkin membangun manusia berkepribadian dan memiliki integritas kejiwaan. Hal itulah yang mendasari adanya konsep pembelajaran pendidikan agama. Tanpa bekal pengetahuan dan bimbingan keagamaan, mustahil membangun manusia Indonesia yang berkualitas kompetitif. 
Dalam kaitannya dengan ruang lingkup pendidikan agama, perlu dibedakan antara pendidikan dan pengajaran. Pendidikan agama pada hakikatnya adalah pendidikan untuk pertumbuhan total seorang anak didik. Pendidikan agama tidak benar jika dibatasi hanya pada pengertian-pengertian yang konvensional dalam masyarakat, seperti mengidentikkan pendidikan agama dengan sekolah di pesantren atau madrasah. Pendidikan formal yang diselenggarakan oleh lembaga pemerintah dan swasta, bagaimanapun bentuknya, tetap lebih banyak tampil dalam bentuk pengajaran.

Pendidikan adalah proses internalisasi budaya ke dalam diri seseorang dan masyarakat sehingga membuat orang dan masyarakat jadi beradab. Pendidikan bukan merupakan sarana transfer ilmu pengetahuan saja, tetapi lebih luas lagi yakni sebagai sarana pembudayaan dan penyaluran nilai (enkulturisasi dan sosialisasi), dalam arti pembentukan karakter yang baik.

Pengajaran agama, sebagaimana yang disinggung Nurcholis Madjid, adalah bagian dari segenap proses pendidikan agama yang hanya menekankan pada ritusritus dan segi-segi formalistiknya belaka. ${ }^{1}$ Pengajaran terkait dengan upaya mentransfer pengetahuan kepada anak didik pada sifat kognitifnya, meski pun tidak dapat dipungkiri adanya sebagian guru di sekolah-sekolah yang juga memerankan pendidikan yang bersifat afektif. Pendekatan afektif dan psikomotorik sesungguhnya banyak diperankan lembaga pendidikan yang menerapkan sistem pendidikan nonformal sebagai pendukung sistem formal seperti pondok pesantren.

Pendidikan karakter memiliki esensi dan makna yang sama dengan pendidikan moral dan pendidikan akhlak. Tujuannya adalah membentuk pribadi anak, supaya menjadi manusia yang baik, warga masyarakat, dan warga negara yang baik. Adapun kriteria manusia yang baik, warga masyarakat yang baik, dan warga negara yang baik bagi suatu masyarakat atau bangsa, secara umum adalah nilai-nilai sosial terten$\mathrm{tu}$, yang banyak dipengaruhi oleh budaya masyarakat dan bangsanya. Oleh karena itu, hakikat dari pendidikan karakter dalam konteks pendidikan di Indonesia adalah pedidikan nilai, yakni pendidikan nilai-nilai luhur yang bersumber dari budaya bangsa Indonesia sendiri, dalam rangka membina kepribadian generasi muda. ${ }^{2}$

Banyak kalangan menaruh harapan besar kepada pondok pesantren -sebagai representasi pendidikan Islam yang sampai sekarang memelihara tradisi budaya dan keilmuan Islam- untuk memposisikan diri di garda depan pembentukan karakter keislaman dan kebangsaan. Pondok pesantren sebagai bagian integral dari institusi pendidikan berbasis masyarakat, menurut Ahmad Tafsir, merupakan sebuah komunitas yang memiliki tata nilai tersendiri. Dengan berlandaskan pada sumber utama agama Islam, al-Qur'an dan Sunnah, pesantren telah dan tetap memainkan peran penting dalam pendidikan karakter Islami. ${ }^{3}$

Pondok Pesantren Hidayatullah, salah satu pondok pesantren di Indonesia yang cukup luas pengaruhnya, dengan ratusan cabang yang tersebar di berbagai wilayah tanah air, telah memberikan kontribusi penting dan sekaligus membuktikan diri sebagai pionir pendidikan Islam yang mengedepankan aspek moralitas dan 
pengamalan nilai-nilai Islam secara kaffah. Para kader dan santrinya tampil di masyarakat sebagai pejuang dan teladan bagi terciptanya masyarakat muslim yang ideal. Dalam pengamatan peneliti, keberhasilan pondok pesantren Hidayatullah sangat ditentukan oleh paradigma pembinaan kadernya yang berbasis pada alQur'an, yaitu berlandaskan pada prinsip-prinsip dan hikmah proses pewahyuan (Sistematika Nuzulnya Wahyu) dan pembentukan masyarakat muslim masa Nabi Muhammad saw.

Paradigma Qur'ani dalam pembentukan individu dan masyarakat muslim yang telah dipraktikkan Nabi Muhammad saw. tersebut dan diterapkan di lingkungan Pondok Pesantren Hidayatullah, dalam pandangan peneliti, sangat urgen untuk diteliti. Atas dasar itulah penelitian ini difokuskan pada salah satu cabang Pesantren Hidayatullah, yaitu Pondok Pesantren Hidayatullah yang terletak di Desa Panyula Kabupaten Bone.

Fokus kajian penelitian ini diarahkan pada pemahaman tentang konsep dan penerapan Sistematika Nuzulnya Wahyu (SNW) sebagai pola dasar pembentukan karakter muslim di Pondok Pesantren Hidayatullah Panyula Kabupaten Bone. Penelitian ini menggunakan pendekatan sosiologis pedagogis dengan metode kualitatif deskriptif yang bertumpu pada observasi dan wawancara mendalam sebagai metode pengumpulan data di lapangan.

\section{PENDIDIKAN KARAKTER}

\section{Pesantren dan Pendidikan Karakter}

Kajian tentang karakter dan pendidikan karakter, baik konsep ontologis normatifnya maupun epistemologis aplikatifnya, telah banyak dilakukan oleh para pakar pendidikan dan sosial. Secara umum, karakter dapat dipahami dalam pengertian berikut:

- Suatu kualitas positif yang dimiliki seseorang sehingga membuatnya menarik dan atraktif

- Reputasi seseorang

- Seseorang yang unusual atau memiliki kepribadian yang eksentrik. ${ }^{4}$

Karakter diartikan sebagai tabiat; watak; sifat-sifat kejiwaan, akhlak atau budi pekerti yang membedakan seseorang dari pada yang lain. Dari pengertian tersebut dapat dikatakan bahwa membangun karakter adalah proses mengukir atau memahat jiwa sedemikian rupa, sehingga 'berbentuk' unik, menarik dan berbeda atau dapat dibedakan dengan orang lain. ${ }^{5}$

Pendidikan karakter, menurut Thomas Lickona, sebagaimana yang dikutip Ratna Megawangi, adalah pendidikan untuk membentuk kepribadian seseorang melalui pendidikan budi pekerti, yang hasilnya terlihat dalam tindakan nyata seseorang, yaitu tingkah laku yang baik, jujur, bertanggung jawab, menghormati hak orang lain, kerja keras dan sebagainya. Pandangan ini dapat dikaitkan dengan tujuan ta'dib, yaitu pengenalan dan afirmasi atau aktualisasi hasil pengenalan. ${ }^{6}$

Pendidikan karakter dapat dimaknai sebagai proses penanaman nilai esensial 
pada diri anak melalui serangkaian kegiatan pembelajaran dan pendampingan, sehingga para siswa sebagai individu mampu memahami, mengalami, dan mengintegrasikan nilai yang menjadi core values dalam pendidikan yang dijalaninya ke dalam kepribadiannya.

Russel William mengilustrasikan bahwa karakter adalah ibarat "otot". "Otot-

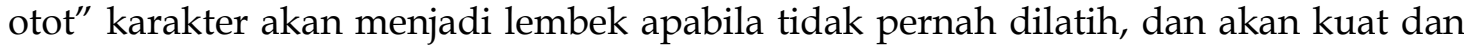
kokoh kalau sering dipakai. Seperti seorang binaragawan (body builder) yang terus menerus berlatih untuk membentuk otot-ototnya. "Otot-otot" karakter juga akan terbentuk dengan praktik-praktik latihan yang akhirnya akan menjadi kebiasaan. ${ }^{7}$

Dalam kaitannya dengan peran pesantren dalam pembentukan karakter, lembaga pendidikan ini memiliki kontribusi yang cukup besar dibandingkan dengan institusi pendidikan Islam lainnya. Pondok pesantren sebagai bagian integral dari institusi pendidikan berbasis masyarakat merupakan sebuah komunitas yang memiliki tata nilai tersendiri. Di samping itu, pesantren mampu menciptakan tata tertib yang unik dan berbeda dari lembaga pendidikan yang lain. Perannya sebagai lembaga pendidikan yang luas penyebarannya di berbagai pelosok tanah air, telah banyak memberikan saham dalam pembentukan Indonesia religius. ${ }^{8}$

Sementara Koesoema, mengemukakan bahwa pendidikan karakter sebagai sebuah pandangan pedagogik, dipengaruhi oleh tiga matra penting yakni individu, sosial, dan moral. Dalam konteks pendidikan karakter di pesantren, ketiga matra tersebut meliputi santri dan kiai/ustad sebagai individu, lingkungan pesantren dan interaksi ustad-santri sebagai matra sosial, dan pilar pendidikan karakter cinta kepada Allah dan segenap ciptaanya sebagai matra moral. Ketiganya saling terkait dan menjadi serangkaian program yang berjalan sistemik dan prosedural.

Terkait dengan pendidikan karakter, Lickona mengemukakan bahwa proses pendidikan karakter menekankan kepada tiga komponen karakter yang baik (components of good character) yakni moral knowing, moral feeling dan moral action. ${ }^{9}$ Dalam konteks proses pendidikan karakter di pesantren, tahapan moral knowing disampaikan dalam dimensi masjid dan dimensi komunitas oleh para kiai dan ustaz. Adapun moral feeling dikembangkan melalui pengalaman langsung para santri dalam konteks sosial dan personalnya. Aspek emosi yang ditekankan untuk dirasakan para santri meliputi sembilan pilar pendidikan karakter, khususnya pilar rasa cinta Allah dan segenap ciptaanya. Sedangkan moral action meliputi setiap upaya pesantren dalam rangka menjadikan pilar pendidikan karakter rasa cinta Allah dan segenap ciptaanya diwujudkan menjadi tindakan nyata. Hal tersebut diwujudkan melalui serangkaian program pembiasaan melakukan perbuatan yang bernilai baik menurut parameter Allah swt. di lingkungan pesantren.

Dalam mewujudkan moral action, pesantren memperhatikan tiga aspek lainnya terkait dengan upaya perwujudan materi pendidikan menjadi karakter pada diri santri, ketiga aspek tersebut meliputi kompetensi, keinginan, dan kebiasaan. Pembentukan ketiga aspek tersebut diupayakan oleh ustaz secara terpadu dan konsisten yang pada akhirnya diharapkan melahirkan moral action (aksi moral) yang secara spontan 
dilakukan anak, baik di lingkungan pesantren, keluarga, maupun di lingkungan masyarakat.

\section{Pesantren Hidayatullah: Pendidikan Berbasis Qur'ani}

Hidayatullah pada awalnya adalah Yayasan Pondok Pesantren Hidayatullah (YPPH) yang menaungi seluruh lembaga pendidikan Hidayatullah di Indonesia. Yayasan ini didirikan pada tanggal 7 Januari 1973 di Balikpapan oleh mendiang Ustaz Abdullah Said. Selanjutnya berkembang dengan berbagai amal usaha di bidang sosial, dakwah, pendidikan, dan ekonomi serta menyebar ke berbagai daerah di seluruh provinsi di Indonesia. ${ }^{10}$

Sebagai kelanjutan dari upaya untuk membangun sistem organisasi yang unggul dan profesional, maka melalui Musyawarah Nasional I tanggal 9-13 Juli 2000, Hidayatullah mengubah bentuk organisasinya menjadi organisasi massa (ormas) dengan ikon gerakan membangun peradaban Islam. Sebagai ormas, keanggotaan Hidayatullah bersifat terbuka. Demikian pula visi, misi dan konsep dasar gerakannya. Menurut Ahkam Sumadiana, salah satu anggota Dewam Pimpinan Pusat Hidayatullah, perubahan dari bentuk yayasan ke ormas ditujukan agar Hidayatullah lebih dapat mengembangkan kiprah dan misinya secara lebih luas pada berbagai sektor yang tidak mungkin dilakukan jika hanya bertahan sebagai yayasan. 11

Lembaga pendidikan Hidayatullah meliputi Taman Kanak-Kanak dan kelompok bermain pra sekolah, sekolah dasar atau madrasah ibtidaiyah di hampir semua daerah, sekolah menengah pertama/madrasah tsanawiyah dan sekolah menengah atas/madrasah aliyah setidaknya ada di setiap wilayah dan 3 perguruan tinggi di Surabaya, Balikpapan, dan Depok.

Sebagai organisasi massa Islam yang berbasis kader, Hidayatullah menyatakan diri sebagai Gerakan Perjuangan Islam (al-Harakah al-Jihadiyah al-Islamiyah) dengan dakwah dan tarbiyah sebagai program utamanya. Keanggotaan Hidayatullah bersifat terbuka, dimana usahanya berfungsi sebagai basis pendidikan dan pengkaderan. Metode (manhaj) Hidayatullah yaitu berpegang pada Alquran dan sunah sebagai bentuk ketaatan kepada Allah dan Rasul-Nya. Hidayatullah berfokus pada pelurusan masalah akidah, imamah dan jamaah (tajdid); pencerahan kesadaran (tilawah ayatillah); pembersihan jiwa (tazkiyah al-nufus); pengajaran dan pendidikan ( $\mathrm{t} a^{\prime}$ lim al-kitab wa al-hikmah) dengan tujuan akhir melahirkan kepemimpinan dan umat. ${ }^{12}$

Pesantren-pesantren Hidayatullah berfungsi sebagai tempat untuk mendalami ilmu. Pesantren ini dihuni santri yang tinggal di asrama, guru, pengasuh, pengelola, dan jamaah Hidayatullah. Pola pengajaran di Pesantren Hidayatullah adalah sistem pesantren modern, yaitu penggabungan mata ajaran umum dan mata ajaran khusus atau keislaman. Mata ajaran umum sama seperti mata ajaran pada sekolah-sekolah umum lainnya, contohnya matematika, fisika, kimia dll. Mata ajaran khusus yaitu mata ajaran yang berkaitan dengan keislaman, contohnya aqidah, fikih, bahasa Arab, dan hafalan/tahfiz Alquran, serta masih banyak lagi mata ajaran yang lain, sesuai dengan jenjang pendidikan dan letak kampus (contoh: kurikulum di Surabaya sedikit berbeda dengan di Jakarta). 
Pesantren Hidayatullah secara umum merupakan lembaga pendidikan yang menekankan misi penciptaan masyarakat islami yang diwarnai nilai-nilai qur'ani dan pengamalan ajaran Islam secara kaffah. Dalam "Pedoman Organisasi Hidayatullah" disebutkan bahwa tujuan Hidayatullah, salah satunya adalah mencapai ridha Allah swt. melalui tegaknya kalimat tauhid dengan lahirnya "masyarakat qur'ani. ${ }^{13}$

Dalam konteks pesantren di Indonesia, Pesantren Hidayatullah termasuk unik, terutama dilihat dari kecepatannya berkembang. Bersamaan dengan semakin besarnya Pesantren Hidayatullah di Balikpapan, berdiri pesantren-pesantren cabang Hidayatullah di berbagai kota di Indonesia. Pendirian pesantren cabang itu diprakarsai kader-kader Hidayatullah yang sengaja dikirim pimpinan pesantren untuk membangun pesantren cabang. Keberhasilan Hidayatullah membangun pesantren cabang menjadikannya sebagai pesantren yang memiliki "network" di seluruh Indonesia, termasuk cabang yang berada di Panyula Kabupaten Bone.

\section{Pembentukan Karakter Qur'ani dengan Penerapan SNW di Pondok Pesantren Hidayatullah Panyula Bone}

Cita-cita awal Hidayatullah, sebagaimana dituturkan secara panjang lebar oleh Ahkam Sumadiana, Ketua Bidang Perkaderan DPP Hidayatullah, termotivasi oleh spirit untuk merekonstruksi sebuah sistem kehidupan baru sebagai alternatif menggantikan sistem kehidupan yang ada saat ini. Para pendiri Hidayatullah (founding fathers) memiliki cita-cita besar untuk memperjuangkan hadirnya kembali suatu tatanan dunia yang beradab, dibangun di atas landasan Kalimat Tauhid di bawah naungan ridha Allah. Cita-cita ini lahir dipicu oleh keprihatinan atas realitas kehidupan global yang jauh dari nilai-nilai kebenaran dan keadilan.

Konsep perjuangan dan apa yang diteladankan Rasulullah saw. dalam membangun peradaban Islam adalah fungsi dari turunnya wahyu Alquran itu sendiri. Bagaimana persepsi itu dibangun sehingga melahirkan orientasi hidup serta visi ideologis yang kuat, pola transformasi yang menjadi manhaj perjuangan dan ideal masyarakat yang diharapkan, secara sistematis dan mengagumkan ternyata terdapat pada ayat-ayat awal turunnya Alquran, ${ }^{14}$ yang dalam istilah teknisnya di Hidayatullah disebut sebagai Sistematika Nuzul-nya Wahyu. Artinya, ayat-ayat awal tersebut merupakan paradigma perjuangan Rasulullah saw. bersama sahabat dalam membangun peradaban Islam.

Pesantren Hidayatullah, dilihat dari kesejarahannya, berawal dari kelompok atau gerakan keagamaan yang menekankan purifikasi tauhid dan perjuangan menegakkan syariat Islam. Syariat Islam di mata kelompok ini bukan semata-mata dalam pengertian penerapan syariat sebagai hukum positif, lebih dari itu adalah terlaksananya ajaran-ajaran Islam secara kaffah. Di atas segalanya, kelompok-kelompok ini berkeyakinan bahwa Islam menyediakan sistem sosial, politik, pendidikan dan sebagainya yang lengkap dan sempurna. ${ }^{15}$

Pondok Pesantren Hidayatullah Panyula, yang terletak kurang lebih $5 \mathrm{~km}$ dari pusat Kota Watampone, merupakan salah satu institusi pendidikan Islam yang sangat memberikan perhatian pada problem dakwah dan kemerosotan pengamalan 
nilai-nilai agama di Kabupaten Bone secara khusus. Sebagaimana halnya dengan pesantren-pesantren lainnya, Pondok Pesantren Hidayatullah Panyula menyelenggarakan pendidikan kepesantrenan yang meliputi pendidikan formal dan nonformal, namun keunikannya ada pada tanggung jawab pembina pesantren pada aspek pengamalan ajaran Islam dan nilai-nilainya secara total (kaaffah), dengan berlandaskan Sistematika Nuzul Wahyu di atas. Dengan kata lain, Pondok Pesantren Hidayatullah, baik di Panyula maupun di berbagai wilayah di Indonesia, berupaya menerapkan pola hidup islami berbasis qur'ani dengan menekankan pada sisi praktisnya, yaitu pengamalan dan penerapan ajaran Islam dalam segala aspek kehidupan.

Dengan penerapan SNW ini, para pembina pesantren sangat yakin akan memberikan kontribusi yang besar dalam pembentukan karakter keislaman pada para santri (peserta didik). Bercermin pada keberhasilan pola pendidikan Rasulullah, Hidayatullah menerapkan nilai-nilai kependidikan yang terkandung dalam tahapan dan proses pewahyuan sebagai pedoman pembentukan komunitas muslim awal, khususnya pada fase dakwah di Mekah.

Pendidikan di Pondok Pesantren Hidayatullah bertujuan mencetak pemimpin, pekerja keras dan bertanggung jawab, baik kepada dirinya, keluarganya, masyarakat dan agamanya. Karena itu, Hidayatullah didirikan dari nol dengan hanya bermodalkan semangat besar dan kerja keras di siang hari, sebagai perwujudan dari salah satu dimensi kekhalifahan, disertai dengan qiyamullail (salat tahajjud) di malam hari sebagai ekspresi dari penghambaan kepada Allah ('abid).

Ismail, pimpinan Pondok Pesantren Hidayatullah Panyula mengungkapkan bahwa tujuan atau misi pesantren Hidayatullah tidak berbeda dari misi atau tujuan pesantren-pesantren lain, yaitu misi Islam itu sendiri. Namun, dalam pandangannya, pesantren-pesantren yang ada sekarang ini belum optimal dan maksimal dalam pencapaian cita-cita pengembangan dakwahnya, yakni perwujudan kehidupan Islam yang kaaffah. Persoalan kemandegan dakwah inilah yang menjadi perhatian serius the founding father-nya Hidayatullah. Dakwah telah berlangsung puluhan tahun di Indonesia, tapi hasilnya belum signifikan, dibanding dakwah Rasulullah saw. yang hanya berlangsung 23 tahun. Pondok Pesantren Hidayatullah meletakkan misinya pada pembentukan kader-kader Islam yang baik sebagaimana bentukan Rasulullah saw. ${ }^{16}$

\section{Menurutnya:}

Pondok Pesantren Hidayatullah menerapkan manhaj yang mengartikulasikan bagaimana Nabi saw. dahulu memulai bentukan masyarakat qur'ani. Itulah yang yang dimaksud dengan manhaj atau Sistematika Nuzulnya Wahyu. Manhaj ini menggambarkan bagaimana metode Nabi mendidik dan membentuk pribadipribadi Sahabat berdasarkan ayat-ayat yang turun. Saya kira inilah yang paling tepat untuk diterapkan di pesantren. Kader muslim yang diinginkan adalah kader yang dibentuk dari metode yang digunakan Nabi dalam membentuk masyarakat awal muslim. Metode ini dipandang sebagai metode yang murni, lebih islami dan lebih menjamin pencapaian kualitas yang diharapkan dibanding metode-metode lain, terlebih yang diadopsi dari Barat. ${ }^{17}$

Dalam kaitannya dengan pembentukan karakter, Ismail menjelaskan: 
Dengan jadwal aktivitas dan rutinitas kepesantrenan yang kami terapkan di pesantren Hidayatullah ini, para santri dapat dipastikan mengalami perubahan ke arah yang jauh lebih positif. Para santri mendapat gemblengan ketauhidan secara intensif dan pemahaman tentang pola hidup islami serta cita-cita dan ideologi Islam melalui penerapan surah al-Alaq dan al-Qalam. Yang lebih menarik adalah metode tazkiyat al-nafs, yang merupakan metode inti dari pendidikan Islam di Hidayatullah, yaitu pengamalan ibadah yang ketat. Metode ini dilakukan dalam bentuk keharusan untuk memperbanyak baca qur'an (tilawah), kewajiban shalat berjamaah setiap waktu, melakukan qiyamullail secara rutin dan membiasakan membaca zikir dan wirid pagi, sore dan malam. Dalam tata norma yang diberlakukan di pesantren, tidak melakukan shalat berjamaah merupakan pelanggaran berat, itulah yang pada gilirannya diyakini berpengaruh pada pembentukan karakter santri di sini. ${ }^{18}$

Seperti yang dijelaskan sebelumnya, pola pendidikan berbasis qur'ani yang diterapkan Hidayatullah melalui tiga metode, yaitu tilawat al-qur'an, tazkiyat al-nafs, ta'lim al-kitab wa al-hikmah. Tilawat al-qur'an adalah membiasakan santri untuk membaca dan menelaah Alquran secara mendalam agar santri memiliki kedekatan dengan Alquran itu sendiri dan menjadikannya sebagai satu-satunya pedoman hidup yang terbaik. Tazkiyat al-nafs adalah proses dan upaya pensucian jiwa melalui ibadah dan zikir yang ketat. Dengan itu diharapkan akan tercipta pribadi-pribadi yang suci, memiliki kontrol diri yang baik dan mampu menjalani tantangan kehidupan yang berat. Ta'lim al-kitab wa al-hikmah adalah pengajaran ilmu dan hikmah yang bertujuan mencerdaskan para santri dalam memahami ilmu dan ajaran agamanya, yang pada akhirnya akan memperoleh hikmah yang bermanfaat bagi dirinya dan kehidupannya kelak.

Secara umum, kegiatan harian para santri di Pondok Pesantren Hidayatullah Panyula lebih dominan diwarnai oleh pengaplikasian pola hidup yang konsisten pada pengamalan ajaran-ajaran Islam beserta fadhilah-fadhilah-nya. Kegiatan harian dimulai dengan ibadah. Setiap malam, sekitar jam 3 dini hari, santri bangun untuk melaksanakan qiyamullail. Meski bukan ibadah fardu, qiyamulllail ini telah menjadi kewajiban bagi warga Hidayatullah. Tujuan pengamalan qiyamullail agar para santri menyadari pentingnya ibadah tersebut dan merasakan efek-efek spiritual yang ditimbulkan dari rutinitas ibadah tahajjud ini. Selain itu, qiyamullail memang merupakan sarana penting dan modal besar untuk mendapatkan hidayah Allah.

Setiap selesai salat subuh, asar dan isya, santri tidak meninggalkan tempat duduknya dan tetap berada di mesjid untuk membaca Alquran dan wirid-wirid. Kesemuanya ini, qiyamullail, membaca Alquran, dan wiridan merupakan pengamalan dari surah al-Muzammil yang mengacu pada pencapaian tingkat spiritual dan kekuatan batin. Setiap kader yang akan melaksanakan dakwah harus menyiapkan bekal kekuatan jiwa, kesabaran, dan keteguhan sikap untuk menghadapi beratnya tantangan. Dari pengamalan ibadah secara intensif ini diharapkan membentuk karakter kader Hidayatullah yang sejati.

Para santri dilatih untuk mandiri dalam mengatur kehidupannya sehari-hari. Pesantren tidak menyediakan makanan dan karena itu para santri memasak sendiri, 
kecuali yang masih kecil. Lagi pula pesantren mewajibkan seluruh santri berpuasa setiap senin dan kamis. Hal ini ditujukan agar ibadah puasa tidak lagi menjadi beban berat dan pada akhirnya menjadi kebiasaan yang memberikan kesenangan batin bagi para santri sejak usia muda. Santri-santri yang kebetulan berada di luar pesantren dan dan tidak berpuasa Senin-Kamis akan merasakan 'kegalauan' batin.

Pada pembelajaran formal, pesantren memberikan mata pelajaran-mata pelajaran yang ditetapkan oleh Kementerian Agama dengan memberikan penekanan dan porsi yang lebih banyak pada pelajaran agama. Sebelum masuk kelas, mereka melakukan pembersihan di sekitar kelas dan pondok. Di kelas mereka membaca Alquran sebelum memulai pelajaran. Setiap guru dan pembina senantiasa memberikan bimbingan-bimbingan ke arah penguatan ketauhidan

Pada intinya adalah bahwa kehidupan santri diarahkan untuk menampilkan pola dan karakter kehidupan islami secara total. Dalam ungkapan Ismail, santri sengaja ditempatkan dalam sistem kehidupan yang membuatnya 'terjebak' dalam kebaikan. Kebiasaan-kebiasaan dan perlakuan-perlakuan pedagogis tersebut sangat diyakini akan membentuk karakter baik pada diri serta kepribadian santri. Ini satu upaya pengembangan potensi afektifnya dan tidak mengembangkan pengetahuan agama secara kognitif semata.

Setelah mendalami makna lima surah yang menjadi fokus doktrin pada SNW, santri Pondok Pesantren Hidayatullah mendapatkan internalisasi nilai ketauhidan. Bagi mereka, kehidupan muslim harus senantiasa berlandaskan ketauhidan. Jusni misalnya, menolak pemikiran bahwa kebahagiaan dan keselamatan dalam hidup manusia sebenarnya terletak pada kemampuan dirinya untuk mengumpulkan harta sebanyak mungkin dan menduduki jabatan tinggi yang membuat dia bebas berbuat apa saja dan memperoleh apapun yang ia mau. Kebahagiaan, menurutnya, adalah mewujudkan tujuan-tujuan hidup yang ditentukan Allah swt. semata. 19

Santri-santri di pesantren ini tanpa ragu menegaskan bahwa dalam setiap melakukan amalan apapun, baik ibadah formal maupun bukan, selalu dilandasi dengan niat lillah ta'ala. Mereka tidak melakukan perbuatan atau amalan apapun karena mengharap pujian dan penghargaan dari orang lain. Selain itu, mereka sama sekali tidak menggantungkan harapan atau mengharapkan pertolongan kepada selain Allah. Setiap manusia, dalam pandangan mereka, bahkan seluruh alam ini telah ditetapkan takdirnya oleh Allah. Cantik atau jelek, kaya atau miskin, dan untung atau rugi seluruhnya dipasrahkan kepada kehendak Allah. Karena itu, kita tidak perlu menyesali nasib atau membanggakan kelebihan-kelebihan yang dimiliki. ${ }^{20}$

Dalam hal kebiasaan salat berjamaah di pesantren, bagi para santri sangat memberikan pengaruh kejiwaan dalam hubungannya dengan lingkungan sosial. Mereka tetap memahami bahwa salat berjamaah sebenarnya tidak diwajibkan, namun sangat dianjurkan oleh Rasulullah saw. Dengan salat berjamaah, akan terbentuk jiwa sosial dan rasa persaudaraan serta kebersamaan di antara sesama muslim. Orang yang tidak salat jamaah biasanya kurang memiliki kepedulian kepada sesama. Hal ini yang ditampakkan dalam pola dan realitas kehidupan sosial para santri dan komu- 
nitas warga Hidayatullah di Panyula.

Ada beberapa gambaran dari realitas pembentukan karakter yang ditanamkan di Pondok Pesantren Hidayatullah Panyula. Ini dapat dipahami dari pernyataanpernyataan para santri hasil dari pemahaman mereka terhadap makna lima surah awal yang turun kepada Nabi. ${ }^{21}$ Pertama, perbuatan yang baik yang dilakukan kepada orang lain, meski didorong oleh rasa kemanusiaan, namun yang terpenting adalah bahwa segala kebaikan itu pada dasarnya diperintahkan Allah dan diteladankan oleh Rasulullah saw. Tujuan utamanya adalah memperoleh pahala dan kedudukan yang tinggi di sisi Allah. Melakukan kebaikan dengan pertimbangan kemanusiaan bisa jadi akan menimbulkan rasa ingin dipuji (riya) dan mengharapkan penghargaan duniawi.

Kedua, ada perasaan bahagia yang muncul akibat perbuatan baik, dan sebaliknya ada kesedihan yang dirasakan akibat dari perbuatan buruk. Jika seorang muslim belum mampu merasakan kasedihan dan penyesalan jika telah berbuat buruk atau dosa, dan kebaikan yang dilakukan tidak memberikan sedikitpun rasa kebahagiaan di dalam hati nurani, itu bukanlah muslim yang sejati.

Ketiga, bahwa Rasulullah saw. merupakan teladan dan ikutan yang sebenarnya dalam perilaku moral dan karakter keislaman. Bagaimana sejatinya seorang muslim dalam berakidah, beribadah, bermuamalah dengan orang lain, bergaul dalam keluarga, bardakwah amar makruf dan nahi mungkar, dan bagaimana seorang muslim bersabar dalam menghadapi beratnya perjuangan karena Allah, maka Rasulullah saw. dengan pengamalan lima surah tersebut merupakan pedoman yang ideal.

\section{SIMPULAN}

Dari uraian tentang penerapan konsep SNW dalam sistem pendidikan Islam dan pembentukan karakter di Pesantren Hidayatullah Panyula di atas dapat disimpulkan sebagai berikut:

- Pesantren Hidayatullah merupakan lembaga berbasis pendidikan dan pengkaderan. Metode (manhaj) Hidayatullah yaitu berpegang pada Alquran dan sunnah sebagai bentuk ketaatan kepada Allah dan Rasul-Nya. Hidayatullah berfokus pada pelurusan masalah aqidah, imamah dan jamaah (tajdid); pencerahan kesadaran (tilawah ayatillah); pembersihan jiwa (tazkiyah al-nufuus); pengajaran dan pendidikan (ta'lim al-kitaab wa al-hikmah) dengan tujuan akhir melahirkan kepemimpinan dan umat.

- Sistematika Nuzulnya Wahyu merupakan pola, metode dan sekaligus strategi pembentukan karakter kader muslim yang dicita-citakan pesantren Hidayatullah. Lima surah yang diturunkan pada awal risalah Nabi Muhammad, yang dalam istilah teknisnya di Hidayatullah disebut sebagai Sistematika Nuzul-nya Wahyu. Kelima surah inilah merupakan pola dasar pendidikan Islam yang diterapkan di Pesantren Hidayatullah sebagai lembaga pendidikan yang bercitacita membangun peradaban Islam yang berlandaskan tauhid dan ditopang oleh karakter muslim yang qur'ani. 


\section{CATATAN AKHIR}

1. Nurcholis Madjid, Masyarakat Religius, Jakarta: Paramadina, 2000, hal. 92.

2. Akhmad Sudrajat, "Apa Pendidikan Karakter itu?", http//akhmadsudrajat.wordpress.com. diakses tanggal 2 Mei 2012.

3. Soebahar Abd Halim, Wawasan Baru Pendidikan Islam, Jakarta: Kalam Mulia, 2002, h. 67.

4. Ibid.

5. Ibid.

6. Ratna Megawangi, "Mampukah Kita Memperbaiki Kondisi Moral Bangsa?" Suara Pembaharuan, 10 Mei 2000.

7. Bambang Q Anees \& Adang Hambali, Pendidikan Karakter Berbasis Al-Qur'an, Bandung: Simbiosa Rekatama Media, 2008, h. 99.

8. Sofyan Sauri, "Peran Pesantren dalam Pendidikan Karakter", http://1060474.siapsekolah.com, diakses tanggal 5 Mei 2012.

9. Megawangi, op.cit.

10. Profil Pondok Pesantren Hidayatullah, Peran Masa Lalu, Kini dan Masa Depan, Balikpapan: Pondok Pesantren Hidayatullah, t.t., h. 3-8.

11. Ahkam Sumadiana, Pembina dan Ketua Bidang Kaderisasi DPP Hidayatullah, Wawancara, di Ponpes Hidayatullah Makassar, tanggal 5 September 2012.

12. Ibid.

13. Pedoman Organisasi Hidayatullah, Jakarta: DPP Hidayatullah, 2002.

14. Al-'Alaq, Al-Qalam, Al-Muzammil, Al-Mudatstsir dan Al-Fatihah.

15. Jajat Burhanuddin dkk (ed.) Mencetak Muslim Modern: Peta Pendidikan Islam Indonesia, Jakarta: RajaGrafindo Persada, 206, h. 209.

16. Ismail, Pimpinan Pondok Pesantren Hidayatullah Panyula, Wawancara di Panyula Kabupaten Bone, tanggal 9 Oktober 2012.

17. Ismail, Pimpinan Pondok Pesantren Hidayatullah Panyula, Wawancara di Panyula Kabupaten Bone, tanggal 9 Oktober 2012.

18. Ismail, Pimpinan Pondok Pesantren Hidayatullah Panyula, Wawancara di Panyula Kabupaten Bone, tanggal 9 Oktober 2012.

19. Jusni, santriwati Pondok Pesantren Hidayatullah Panyula, Wawancara di Bone, tanggal 20 Oktober 2012.

20. Rumaishah dan Khahiriyah, santriwati Pondok Pesantren Hidayatullah Panyula, Wawancara di Bone, tanggal 20 Oktober 2012.

21. Jusni, Rumaishah dan Khahiriyah, santriwati Pondok Pesantren Hidayatullah Panyula, Wawancara di Bone, tanggal 20 Oktober 2012

\section{DAFTAR PUSTAKA}

Anees, Bambang Q \& Adang Hambali, Pendidikan Karakter Berbasis Al-Qur'an, Bandung: Simbiosa Rekatama Media, 2008..

Burhanuddin, Jajat, dkk (ed.) Mencetak Muslim Modern: Peta Pendidikan Islam Indonesia, Jakarta: RajaGrafindo Persada, 2006.

Madjid, Nurcholis, Masyarakat Religius, Jakarta: Paramadina, 2000.

Megawangi, Ratna, “Mampukah Kita Memperbaiki Kondisi Moral Bangsa?" Suara Pembaharuan, 10 Mei 2000.

Pedoman Organisasi Hidayatullah, Jakarta: DPP Hidayatullah, 2002.

Profil Pondok Pesantren Hidayatullah, Peran Masa Lalu, Kini dan Masa Depan, Balik Papan: Pondok Pesantren Hidayatullah, t.t. 
Sauri, Sofyan, "Peran Pesantren dalam Pendidikan Karakter", http://1060474.siapsekolah.com, diakses tanggal 5 Mei 2012.

Soebahar, Abd Halim, Wawasan Baru Pendidikan Islam. Jakarta: Kalam Mulia. Jakarta, 2002.

Sudrajat, Akhmad, "Apa Pendidikan Karakter itu?", http//akhmadsudrajat. wordpress. com. diakses tanggal 2 Mei 2012. 